1 Title: A gene expression map of host immune response in human brucellosis

3 Authors: Ioannis Mitroulis ${ }^{1,2}$, Akrivi Chrysanthopoulou ${ }^{1}$, Georgios Divolis ${ }^{3}$,

4 Charalampos Ioannidis $^{4}$, Maria Ntinopoulou ${ }^{1}$, Athanasios Tasis ${ }^{1}$, Theocharis

5 Konstantinidis $^{1,5}$, Natalia Soteriou ${ }^{6}$, George Lallas ${ }^{6}$, Stella Mitka ${ }^{7}$, Mathias Lesche ${ }^{8}$,

6 Andreas Dahl ${ }^{8}$, Stephanie Gembardt ${ }^{4}$, Maria Panopoulou ${ }^{5}$, Paschalis Sideras ${ }^{3}$, Ben

7 Wielockx ${ }^{4}$, Ünal Coskun ${ }^{4}$, Konstantinos Ritis $^{1,2}$, Panagiotis Skendros ${ }^{1,2} *$

9 Affiliations: ${ }^{1}$ Laboratory of Molecular Hematology, Democritus University of

10 Thrace, University Hospital of Alexandroupolis, Alexandroupolis, Greece, ${ }^{2}$ First

11 Department of Internal Medicine, Democritus University of Thrace, University

12 Hospital of Alexandroupolis, Alexandroupolis, Greece; ${ }^{3}$ Biomedical Research

13 Foundation Academy of Athens, Center for Clinical, Experimental Surgery and

14 Translational Research, Athens, Greece; ${ }^{4}$ Institute for Clinical Chemistry and

15 Laboratory Medicine, Faculty of Medicine, Technische Universität Dresden, 01307

16 Dresden, Germany; ${ }^{5}$ Laboratory of Microbiology, Democritus University of Thrace,

17 University Hospital of Alexandroupolis, Alexandroupolis, Greece; ${ }^{6} \mathrm{P}$. Zafiropoulos

18 SA, Athens, Greece; ${ }^{7}$ School of Biomedical Sciences, International Hellenic

19 University, Thessaloniki, Greece; ${ }^{8}$ DRESDEN-concept Genome Center, c/o Center

20 for Molecular and Cellular Bioengineering, Technische Universität Dresden, Dresden,

21 Germany

\title{
23 *Correspondence:
}

24 Panagiotis Skendros, MD, PhD, University Hospital of Alexandroupolis, Dragana, 25 Alexandroupolis 68100, Greece. E-mail: pskendro@med.duth.gr 
medRxiv preprint doi: https://doi.org/10.1101/2022.03.01.22271720; this version posted March 4, 2022. The copyright holder for this preprint (which was not certified by peer review) is the author/funder, who has granted medRxiv a license to display the preprint in perpetuity.

It is made available under a CC-BY-NC-ND 4.0 International license .

\section{ABSTRACT}

27 Brucellosis is a common zoonotic disease caused by intracellular pathogens of the

28 genus Brucella. Brucella infects macrophages and evades clearance mechanisms,

29 which results in chronic parasitism. Herein, we studied the molecular changes that

30 take place in human brucellosis both in vitro and in vivo. RNA sequencing was

31 performed in primary human macrophages $(\mathrm{M} \varphi)$ and polymorphonuclear neutrophils

32 (PMNs) infected with clinical strains of B. melitensis. We observed a downregulation

33 in the expression of genes involved in host response, such as TNF signaling, IL-1 $\beta$

34 production and phagosome formation in $\mathrm{M} \varphi$, and phosphatidylinositol signaling and

35 TNF signaling in PMNs, being in line with the ability of the pathogen to survive

36 within phagocytes. Further transcriptomic analysis of isolated peripheral blood

37 mononuclear cells (PBMCs) and PMNs from patients with acute brucellosis before

38 treatment initiation and after successful treatment revealed a positive correlation of

39 the molecular signature of active disease with pathways associated with response to

40 interferons (IFN). We identified 24 common genes that were significantly altered in

41 both PMNs and PBMCs, including genes involved in IFN signaling that were

42 downregulated after treatment in both cell populations, and ILIRI that was

43 upregulated. The levels of several inflammatory mediators were evaluated in the

44 serum of these patients, and we observed increased levels of IFN- $\gamma$, IL-1 $\beta$ and IL-6

45 before the treatment of acute brucellosis. An independent cohort of patients with

46 chronic brucellosis also revealed the increased levels of IFN- $\gamma$ during relapse

47 compared to remissions. Taken together, this study provides for the first time an in-

48 depth analysis of the molecular alterations that take place in human phagocytes upon

49 infection, and in peripheral blood immune populations during active disease. 
medRxiv preprint doi: https://doi.org/10.1101/2022.03.01.22271720; this version posted March 4, 2022. The copyright holder for this preprint (which was not certified by peer review) is the author/funder, who has granted medRxiv a license to display the preprint in perpetuity. It is made available under a CC-BY-NC-ND 4.0 International license.

\section{Keywords}

51 Brucellosis; immunity; transcriptomics; macrophages; polymorphonuclear

52 neutrophils; peripheral blood mononuclear cells 
medRxiv preprint doi: https://doi.org/10.1101/2022.03.01.22271720; this version posted March 4, 2022. The copyright holder for this preprint (which was not certified by peer review) is the author/funder, who has granted medRxiv a license to display the preprint in perpetuity.

It is made available under a CC-BY-NC-ND 4.0 International license .

\section{INTRODUCTION}

54 Brucellosis is a common bacterial zoonotic disease worldwide and an emerging

55 zoonosis in several developed countries $(1,2)$. Despite its importance in public health

56 remains widespread and neglected in many areas, including southeastern Europe,

57 Asia, Central and Latin America, and Africa (2,3). It is caused by intracellular

58 pathogens of the genus Brucella that have domestic animals, mainly goats, sheep and

59 cows, as natural reservoirs. The disease is transmitted to humans by consumption of

60 unpasteurized milk and dairy products or by occupational contact with infected

61 animals (4). Additionally, Brucella is highly infectious through the aerosol route, thus

62 is considered as one of the most common laboratory-acquired pathogens and is also

63 classified as a category B agent on the biodefense list $(5,6)$.

64 Human brucellosis causes high morbidity and protean clinical manifestations,

65 mimicking many infectious and non-infectious diseases since it can affect multiple

66 organs. Despite early diagnosis and prolonged therapy with antibiotics is associated

67 with substantial residual disability $(4,7)$. Up to $30 \%$ of patients develop chronic

68 disease, which is characterized by atypical clinical manifestations, high frequency of

69 focal complications such as spondylitis, chronic fatigue syndrome, and relapses $(7,8)$.

70 Host protection against Brucella and prevention of its intracellular parasitism in

71 macrophages depends on cell-mediated immunity, involving adequate Th1 immune

72 response, with significant production of interferon gamma (IFN- $\gamma)(8)$. Recent data

73 support also an emerging key role of innate immunity and neutrophils in early

74 proinflammatory responses against Brucella that may affect T-cell dynamics during

75 infection $(9,10)$. On the other hand, Brucella has developed various stealthy strategies

76 to evade innate and adaptive immune responses, in order to establish intracellular

77 long-term survival and replication $(9,11)$. Several studies have demonstrated that 
78 patients with chronic brucellosis display defective cell-mediated immunity

79 (brucellosis-acquired cellular anergy) probably due to modulation of host cellular

80 immunity by Brucella (12). However, immunopathogenesis of human brucellosis

81 remains incompletely understood and integrated molecular data that characterize

82 complex interactions between Brucella and host immunity are missing today.

83 Here, we provide a gene expression map that guides the molecular signature of

84 macrophages $(\mathrm{M} \varphi)$ and polymorphonuclear neutrophils (PMNs) during the crucial

85 early events of Brucella infection. Moreover, we analyse the transcriptomic alterations

86 that take place concomitantly in peripheral blood mononuclear cells (PBMCs) and

87 PMNs of patients upon treatment uncovering candidate molecular targets and

88 pathways that may characterize active infection and disease eradication. 
medRxiv preprint doi: https://doi.org/10.1101/2022.03.01.22271720; this version posted March 4, 2022. The copyright holder for this preprint (which was not certified by peer review) is the author/funder, who has granted medRxiv a license to display the preprint in perpetuity.

It is made available under a CC-BY-NC-ND 4.0 International license .

\section{MATERIALS AND METHODS}

\section{Patients}

91 Ten adult patients with acute brucellosis were recruited. EDTA anticoagulated blood

92 and serum were collected from patients with active brucellosis before the initiation of

93 antibiotic treatment and three months after the completion of treatment, when all

94 patients were successfully treated. The diagnosis was based on compatible clinical

95 manifestations in combination with high serum titers of anti-brucellar antibodies

96 (Wright's agglutination test $\geq 160$ ) or a four-fold increase of the initial titers in two-

97 paired samples drawn 2 weeks apart, or/and Brucella isolation. None of these patients

98 suffered any relapse during a six-month post-treatment follow-up period. Patient

99 characteristics and treatment are described in Table 1. PBMCs and PMNs were

100 simultaneously isolated. RNA was isolated using TRIzol reagent (ThermoScientific).

101 Sera from a second cohort of 25 chronic relapsing brucellosis patients at clinical

102 relapse and remission, were also used. These patients had a disease duration of $\geq 12$

103 months in combination with positive serum agglutination tests (SATs) or/and

104 complement fixation test, or/and Brucella isolation (Supplementary Table 1).

105 Exclusion criteria were co-existence of other infectious, neoplasmatic or autoimmune

106 disease, administration of immunomodulating agents or vaccination for at least 4

107 weeks before the entry to study, and pregnancy. The study was approved by the Local

108 Scientific and Ethics Committee of the University Hospital of Alexandroupolis,

109 Greece. All subjects provided written informed consent in accordance with the

110 principles expressed in the Declaration of Helsinki.

\section{M $\varphi$ differentiation}

112 Human $\mathrm{M} \varphi$ were differentiated from isolated PBMCs from four control subjects, as

113 previously described with modifications (13). In brief, PBMCs were isolated from 
medRxiv preprint doi: https://doi.org/10.1101/2022.03.01.22271720; this version posted March 4, 2022. The copyright holder for this preprint (which was not certified by peer review) is the author/funder, who has granted medRxiv a license to display the preprint in perpetuity.

It is made available under a CC-BY-NC-ND 4.0 International license .

114 healthy donors by density gradient centrifugation, using Histopaque 1077 (Sigma). To

115 promote $\mathrm{M} \varphi$ differentiation, monocytes were isolated using plastic adherence and

116 cells were cultured in the presence of $10 \%$ autologous serum for 6 days.

\section{In vitro infection}

118 Clinical strains of B. melitensis were used for in vitro experiments. Bacterial inoculum

119 for cell infection was cultured on blood agar for 3 days. Bacterial suspension with 0.5

120 McFarland was opsonized for 30 minutes using human serum and then diluted in

121 RPMI and $\sim 10^{7}$ bacteria in $0.5 \mathrm{ml}$ of RPMI were added to each well (20 MOI) of

122 PMNs or M $\varphi$. Subsequently, cells were cultured for $0.5 \mathrm{~h}$ for PMNs and $2 \mathrm{~h}$ and $24 \mathrm{~h}$

123 for $\mathrm{M} \varphi$, washed twice and RNA was isolated, using TRIzol reagent

124 (ThermoScientific). Untreated PMNs and untreated $\mathrm{M} \varphi$, cultured for $2 \mathrm{~h}$ served as

125 control, respectively. The experimental procedure with B. melitensis was performed at

126 biosafety level 3.

127 RNA sequencing

128 RNA sequencing for $\mathrm{M} \varphi$ and PBMCs was performed as previously described (14). To

129 analyze RNA sequencing data, fragments were aligned with GSNAP (2020-12-16) to

130 the human reference (hg38), and Ensembl annotation version 98 was used for the

131 splice site support. Uniquely aligned fragments were counted with featureCounts

132 (subread v2.0.1), again with the support of the Ensembl annotation. The exploratory

133 analysis was performed with the DESeq 2 (v1.24.0) package within R (v3.6.3). Bias

134 for patients was assessed using an exploratory correction with the variance stabilized

135 transformation data of DESeq2 and the removeBatchEffect function of edgeR

136 (3.26.8). Differential expression between before and after treatment was performed

137 with a correction for patient. 
medRxiv preprint doi: https://doi.org/10.1101/2022.03.01.22271720; this version posted March 4, 2022. The copyright holder for this preprint (which was not certified by peer review) is the author/funder, who has granted medRxiv a license to display the preprint in perpetuity.

It is made available under a CC-BY-NC-ND 4.0 International license .

138 For PMNs, 1000 ng of total RNA were used for the preparation of cDNA libraries,

139 using the TruSeq RNA Library Preparation Kit v2 (Illumina), according to the

140 manufacturer's instructions. Library quality was evaluated using the Agilent DNA

$1411000 \mathrm{Kit}$ (Agilent) with an Agilent 2100 Bioanalyzer. Quantification was performed

142 by amplifying a set of six pre-diluted DNA standards (KAPA Biosystems) and diluted

143 cDNA libraries by RT-qPCR. Isomolar quantities of up to 20 cDNA libraries,

144 barcoded with different adaptors, were multiplexed. Sequencing was performed in a

145 single-end manner at the Greek Genome Center, using a NextSeq 500/550 75c kit

146 (Illumina) for the in vitro samples and a NovaSeq 6000 SP 100c kit (Illumina) for the

147 ex vivo samples, generating $75 \mathrm{bp}$ and $100 \mathrm{bp}$ long reads, respectively, and an average

148 of 25 million reads per library. Raw sequence data in FastQ format were uploaded to

149 the Galaxy web platform, and standard tools of the public server "usegalaxy.org" were

150 used for subsequent analysis (15). Briefly, quality control of raw reads was performed

151 with FastQC (v072+galaxy1), followed by removal of adapter sequences and low-

152 quality bases using Trim Galore! (v0.6.3). Next, HISAT2 (v2.2.1+galaxy0) was

153 applied for the alignment of trimmed reads to the Homo sapiens (human) genome

154 assembly GRCh37 (hg19) from Genome Reference Consortium. Assessment of

155 uniform read coverage for exclusion of $5^{\prime} / 3^{\prime}$ bias and evaluation of RNA integrity at

156 the transcript level were performed using Gene Body Coverage (v2.6.4.3) and

157 Transcript Integrity Number (v2.6.4.1) tools, respectively. Differential gene

158 expression was determined with DESeq2 (v2.11.40.6+galaxy1), using the count tables

159 generated from HTSeq-count (v0.9.1) as input. The variability within and between

160 individuals of this paired-data study was incorporated in the analysis, considering the

161 treatment as the primary factor and the individual/patient as the secondary factor

162 affecting gene expression. 
163 Pathway and biological processes analysis was performed using the Enrichr analysis

164 tool $(14,16)$. Heat maps were generated using the Morpheus software (Broad

165 Institute). Gene set enrichment (GSEA) pre-ranked analysis (1000 permutations,

166 minimum term size of 15 , maximum term size of 500) was performed using the

167 GSEA software (Broad Institute). Gene sets were ranked by taking the $-\log 10$

168 transform of the $\mathrm{p}$-value and signed as positive or negative based on the direction of

169 fold change. Annotated gene sets from Molecular Signatures Database (MSigDB)

170 were used as input (16).

\section{Cytokine measurement}

172 The levels of cytokines were measured using the LEGENDplex ${ }^{\mathrm{TM}}$ Multi-Analyte

173 Flow Assay Kit (Biolegend) in a CyFlow Cube 8 flow cytometer (Sysmex Partec,

174 Germany), according to manufacturer's instructions. For comparisons between the

175 groups the Wilcoxon signed-rank test for paired samples was used. Statistical analysis

176 was performed using GraphPad Prism (GraphPad Inc., La Jolla, CA). Significance

177 was set at $\mathrm{p}<0.05$. 
medRxiv preprint doi: https://doi.org/10.1101/2022.03.01.22271720; this version posted March 4, 2022. The copyright holder for this preprint (which was not certified by peer review) is the author/funder, who has granted medRxiv a license to display the preprint in perpetuity.

It is made available under a CC-BY-NC-ND 4.0 International license .

\section{RESULTS}

179 Analysis of the molecular signature of human macrophages infected in vitro with

\section{B. melitensis}

181 To provide a time-course analysis of the molecular alterations of human $\mathrm{M} \varphi$ during

182 infection with $B$. melitensis, we performed in vitro infection of human $\mathrm{M} \varphi$, derived

183 from the differentiation of peripheral blood monocytes from control subjects, and

184 compared the transcriptomic signature of untreated $\mathrm{M} \varphi$ compared to that of infected

185 cells at $2 \mathrm{~h}$ and $24 \mathrm{~h}$ post-infection. Principal component analysis (PCA) revealed that

186 there was a prominent change in the transcriptomic profile of $\mathrm{M} \varphi$ at $24 \mathrm{~h}$ after

187 infection compared to untreated cells and cells at $2 \mathrm{~h}$ after infection (Figure 1A).

188 Pathway analysis, using the Kyoto Encyclopedia of Genes and Genomes (KEGG)

189 database, of the significantly upregulated differentially expressed genes (DEG) (False

190 Discovery Rate/FDR <0.01) between untreated $\mathrm{M} \varphi$ and $\mathrm{M} \varphi$ at $2 \mathrm{~h}$ post-infection

191 revealed an overrepresentation of circadian rhythm and ribosome biogenesis

192 pathways, whereas downregulated DEGs were enriched in pathways associated with

193 viral infection and infection from intracellular pathogens processes, including herpes

194 simplex virus 1 infection, hepatitis C, and salmonella infection and TNF signaling

195 (Figure 1B, C). Interestingly, we observed a decreased expression of genes encoding

196 proteins critical in pathogen recognition, such as NOD1, TLR5, TLR6 and NLRC4

197 (Figure 1C).

198 We next assessed the molecular changes that take place at $24 \mathrm{~h}$ post-infection. Pathway

199 analysis of the downregulated DEGs with the highest variance ( $\log 2$ fold change $>2$

200 and $<-2$, FDR $<0.01)$ showed overrepresentation of pathways associated with

201 infection with Staphylococcus aureus and infection with intracellular pathogens, such

202 as leishmaniasis and tuberculosis, as well as the pathways associated with phagosome 
medRxiv preprint doi: https://doi.org/10.1101/2022.03.01.22271720; this version posted March 4, 2022. The copyright holder for this preprint (which was not certified by peer review) is the author/funder, who has granted medRxiv a license to display the preprint in perpetuity.

It is made available under a CC-BY-NC-ND 4.0 International license .

203 and lysosome (Figure 1D). No statistically significant pathway was observed at the

204 respective analysis of upregulated genes. Further, analysis of the DEGs that were

205 downregulated at $24 \mathrm{~h}$ after infection revealed that they are involved in biological

206 processes associated with inflammation, and more specifically with the production of

207 IL-1 and $\mathrm{M} \varphi$ function (Figure 1E). Regarding the genes involved in the

208 aforementioned pathways, there was a downregulation of several genes involved in

209 the phagosome formation and function at $24 \mathrm{~h}$ after infection, including those

210 encoding for several $\mathrm{Fc} \gamma$ receptors (FCGR1A, FCGR2A, FCGR2B, FCGR2C,

211 FCGR3A, FCGR3B), toll-like receptors (TLR2, TLR4, TLRO), other sensors of

212 pathogen-associated molecular patterns (CLEC7A, CD14), integrins and other

213 receptors involved in phagocytosis (ITGB3, ITGAM, ITGB2, CD36) (Figure 3D). We

214 also observed a downregulation in the expression of genes encoding cytokines and

215 cytokine receptors of the IL-1 family (IL18, ILIRN, IL36RN), chemokines (CCL1,

216 CCL2, CCL7, CCL8, CCL13, CXCL9) and chemokine receptors (CCR1, CCR2,

217 CCR3, CCR5), formyl peptide receptors (FPR1, FPR2, FPR3), and complement

218 anaphylatoxin receptors (C3AR1, C5AR1, C5AR2) (Figure 1F). Regarding the

219 regulation of IL-1 production, we observed the downregulation of several genes

220 encoding inflammasome sensors (NLRC4, NLRP12, MEFV, AIM2), the adaptor

221 PYCARD, and the gene that encodes the effector CASPI (Figure 1F). Taken together,

222 infection of $\mathrm{M} \varphi$ with $B$. melitensis drives major changes in the transcriptomic profile

223 of infected $\mathrm{M} \varphi$, downregulating a plethora of genes involved in the formation of

224 phagosomes and the recognition of pathogens, in an effort to preserve pathogen

225 survival within $\mathrm{M} \varphi$.

226 
medRxiv preprint doi: https://doi.org/10.1101/2022.03.01.22271720; this version posted March 4, 2022. The copyright holder for this preprint (which was not certified by peer review) is the author/funder, who has granted medRxiv a license to display the preprint in perpetuity.

It is made available under a CC-BY-NC-ND 4.0 International license .

\section{Analysis of the molecular signature of human PMNs infected in vitro with $B$.}

228

229

230

231

232 performed in vitro infection of human PMNs for $0.5 \mathrm{~h}$, derived from control subjects,

233 and compared the transcriptomic signature of untreated PMNs to that of infected cells.

234 Pathway analysis of the significantly overexpressed DEGs (FDR $<0.01)$, using the

235 KEGG database, highlighted Ribosome as the top upregulated pathway in Brucella-

236 infected PMNs (Figure 2A). Notably, almost all genes (75 out of the 79) encoding for

237 structural proteins of both small and large subunits of cytoplasmic ribosomes were

238 found significantly upregulated (Figure 2B). Respective analysis of the downregulated

239 DEGs demonstrated modulation of several pathways, some of which were also

240 downregulated in Brucella-infected $\mathrm{M} \varphi$ at $2 \mathrm{~h}$ post-infection, such as TNF signaling

241 and herpes simplex virus 1 infection (Figures 1B and 2C). However, various

242 inflammation-related biological processes were significantly downregulated

243 selectively in PMNs, namely the phosphatidylinositol signaling, NF-kappa B

244 signaling, and cellular senescence pathways (Figure 2B, C). Amongst the

245 downregulated transcripts in Brucella-infected PMNs, we identified several

246 modulators of apoptosis (BIRC3, FOXO3, DNM1L, ITPR1, TRAF1, TRAF5) and

247 inflammation, as exemplified by decreased mRNA expression of cytokines and

248 corresponding receptors of the IL-1 family (ILIA, ILIB, ILI8RI), chemokines (eg.

249 CCL20), and various signaling mediators, such as kinases (AKT3, ATM, ATR, CDK6,

250 DGKD, DGKE, IPMK, IPPK, MAPK13, MAPK14, RPK1) (Figure 2C). 
medRxiv preprint doi: https://doi.org/10.1101/2022.03.01.22271720; this version posted March 4, 2022. The copyright holder for this preprint (which was not certified by peer review) is the author/funder, who has granted medRxiv a license to display the preprint in perpetuity.

It is made available under a CC-BY-NC-ND 4.0 International license .

\section{Transcriptomic profiling of active human brucellosis}

253 We further investigated the transcriptomic signature of active human brucellosis. To

254 do so, PMNs were isolated from eight patients with active brucellosis before the

255 initiation of antibiotic treatment (active disease) and three months after completion of

256 the antibiotic treatment, when patients were free of symptoms (remission).

257 Transcriptomic analysis identified 318 DEGs (FDR $<0.1$ ) (Figure 3A). DEGs that

258 were upregulated after treatment are involved in RNA transport and autophagy

259 pathways, whereas downregulated DEGs after treatment are involved in NOD-like

260 receptor signaling pathway and cytokine-cytokine receptor interaction pathways, as

261 well as several pathways associated with infectious diseases (Figure 3A). The

262 upregulated genes that encode proteins involved in RNA transport were the members

263 of the eukaryotic initiator factors (EIF) family EIF1, EIF3I, EIF4A3, EIF5, and the

264 genes of the autophagy pathway were ATG2A, GABARAPL1, TP53INP2, DDIT4 and

265 IRS2 (Figure 3B). On the other hand, we observed a downregulation of critical genes

266 in immune regulation, such as IL1B, CX3CR1, CCR2, CCR5, CXCR6, STAT1, AIM2,

267 and $C D 40$, as well as genes associated with interferon signaling, such as OAS1, OAS2,

$268 G B P 1$ and GPB3 (Figure 3B). We further performed gene set enrichment analysis

269 (GSEA) using the Hallmark Gene Set collection of the Molecular Signatures

270 Database. We observed a positive correlation of the transcriptomic signature of PMNs

271 during active brucellosis with IFN- $\gamma$ and IFN- $\alpha$ response and with inflammatory

272 response (Figure 3).

273 In parallel, we performed transcriptomic analysis of PBMCs isolated from six patients

274 with active brucellosis before and after antibiotic treatment. Transcriptomic analysis

275 identified 62 genes with significantly altered expression $($ FDR $<0.1)$ after treatment

276 (Figure 4A). We observed that successful treatment resulted in the increased 
medRxiv preprint doi: https://doi.org/10.1101/2022.03.01.22271720; this version posted March 4, 2022. The copyright holder for this preprint (which was not certified by peer review) is the author/funder, who has granted medRxiv a license to display the preprint in perpetuity.

It is made available under a CC-BY-NC-ND 4.0 International license .

277 expression of $H I F 1 A$, a critical regulator of inflammation, and of the genes that

278 encode IL-1 receptor $I L 1 R I$, and its accessory protein $I L 1 R A P$, which form a complex

279 that mediates IL-1 signal transduction (Figure 4A). On the other hand, there was a

280 downregulation in the expression of genes that play a major role in immune function,

281 such as CD274, which encodes PD-L1, STAT1, CD3G, the intracellular

282 immunoglobulin receptor TRIM21, CXCR6, the lymphocytic activation molecules

283 SLMF6, SLAMF7 and genes that encode proteins important in effector cell cytolytic

284 processes, such as CD160, GZMA, GZMH (Figure 4A). Moreover, several identified

285 genes are involved in interferon-related activation pathways, such as $G P B 3, G P B 4$,

286 OAS1, OAS2, OASL, IFI16, and XAF1 (Figure 4A). To the same line, GSEA analysis

287 revealed that the gene sets with the most significant positive association with active

288 disease were IFN signaling and OXPHOS, whereas the one with the most significant

289 negative association was the hypoxia gene set (Figure 4B). Notably, we further

290 identified 24 genes that were differentially expressed both in PMNs and PBMCs

291 (Figure 4C). Among these common genes, CXCR6, TRIM21, SLAM7, CD274 and the

292 genes associated with IFN signaling OASL, OAS1, OAS2, GBP3, and STAT1 were

293 downregulated in both datasets, whereas ILIRI was commonly upregulated (Figure

294 4D).

295 Cytokine levels in acute brucellosis

296 To this point, we observed that the molecular signature that characterizes acute

297 brucellosis is positively correlated with those of IFN- $\alpha$ and IFN- $\gamma$ response. For this

298 reason, we measured the levels of several cytokines in the sera of patients during

299 acute brucellosis and after successful treatment. We observed a significant

300 downregulation in the levels of IFN- $\gamma$, IL-1 $\beta$ and IL- 6 post-treatment, whereas there

301 was no statistically significant difference in the levels of IFN- $\alpha$, IL-18, TNF, MCP-1 
medRxiv preprint doi: https://doi.org/10.1101/2022.03.01.22271720; this version posted March 4, 2022. The copyright holder for this preprint (which was not certified by peer review) is the author/funder, who has granted medRxiv a license to display the preprint in perpetuity. It is made available under a CC-BY-NC-ND 4.0 International license .

302 and IL-17A (Figure 5A-H). We further confirmed that the levels of IFN- $\gamma$ are

303 increased in active disease in a cohort of patients with chronic relapsing brucellosis.

304 In this cohort, the levels of IFN- $\gamma$ were increased during relapse compared to 305 remission (Figure 5I). 
medRxiv preprint doi: https://doi.org/10.1101/2022.03.01.22271720; this version posted March 4, 2022. The copyright holder for this preprint (which was not certified by peer review) is the author/funder, who has granted medRxiv a license to display the preprint in perpetuity.

It is made available under a CC-BY-NC-ND 4.0 International license .

\section{DISCUSSION}

307 The interaction between Brucella and host immune system is critical for the

308 development of persistent infection or infection clearance $(8,18)$. To date,

309 transcriptomic data derived from Brucella-infected mouse macrophages or mouse cell

310 lines, domestic ruminants or Brucella-vaccinated animals (19-25). This study

311 analyses, for the first time, the transcriptome profile, both in vitro, in Brucella-

312 infected primary $\mathrm{M} \varphi$ and PMNs, and ex-vivo, in PBMCs and PMNs derived from

313 patients with acute brucellosis before and after treatment. This provides the molecular

314 signature that characterizes the main host cellular immune populations during their

315 initial interplay with invading Brucella, and the molecular signature of different stages

316 of the disease.

317 Early molecular events following phagocytosis of Brucella by macrophages are

318 crucial for the activation of innate immunity leading to the induction of a favorable

319 Th1 response $(8,18)$. Several lines of evidence indicated that Brucella manipulates

320 multiple effector mechanisms in macrophages to its own benefit $(9,12)$. In line with

321 this, we identified that in $\mathrm{M} \varphi$ infected in vitro by a clinical strain of $B$. melitensis, the

322 expression of several genes encoding key proteins involved in the recognition of

323 Brucella and in the proinflammatory response against the pathogen were markedly

324 suppressed. These alterations may initiate as soon as $2 \mathrm{~h}$ post-infection being more

325 prominent at $24 \mathrm{~h}$ post infection. Interestingly, most downregulated DEGs related to

326 phagosome, TNFa signaling and IL-1 $\beta$ production. Indeed, previous studies reported

327 that various Brucella virulence factors and pathogen-associated molecular patterns

328 (PAMPs), such as Type IV secretory system (T4SS), lipopolysaccharide (LPS) and

329 outer membrane lipoproteins (OMPs) modify phagosome biogenesis and trafficking

330 in macrophages to inhibit phagolysosome fusion, and develop suitable vacuolar 
medRxiv preprint doi: https://doi.org/10.1101/2022.03.01.22271720; this version posted March 4, 2022. The copyright holder for this preprint (which was not certified by peer review) is the author/funder, who has granted medRxiv a license to display the preprint in perpetuity.

It is made available under a CC-BY-NC-ND 4.0 International license .

331 compartments to enable intracellular replication of the microbe $(9,12)$. Moreover, the

332 current study comes in agreement with previous data demonstrated that Brucella

333 Omp25 protein inhibits in vitro the production of TNF in human M $\varphi$ and dendritic

334 cells preventing cell maturation and antigen presentation (26-28). Furthermore,

335 several genes encoding members of the IL-1 family (IL18, ILIRN, IL36RN) and

336 inflammasome complexes (NLRC4, NLRP12, MEFV, AIM2, PYCARD, CASP1) are

337 significantly downregulated in Brucella-infected $\mathrm{M} \varphi$. Experimental studies indicated

338 that inflammasomes and their effectors are essential for an initial effective immune

339 response against Brucella infection (29-31). On the other hand, Brucella can regulate

340 canonical and non-canonical inflammasome signaling and pyroptosis in macrophages

341 by impairing caspase- 1 and caspase- $4 / 11$ activation, and IL- $1 \beta$ secretion $(32,33)$. It is

342 intriguing that Brucella downregulates macrophage $M E F V$ expression, the gene

343 responsible for familial Mediterranean fever, the prototype IL-1 $\beta$-mediated

344 autoinflammatory disease (34). Mutations in the $M E F V$ gene are highly prevalent in

345 the Middle East and Mediterranean countries where brucellosis is endemic (35). Our

346 data further support the hypothesis that $M E F V$ mutations may provide an evolutionary

347 selective advantage to confer protection against brucellosis (36).

348 Recently, PMNs emerge as novel players during the initial stages of innate immune

349 response against Brucella infection (10). Brucella resists the killing mechanisms of

350 human PMNs and induces the early death of these cells promoting their phagocytosis

351 by $\mathrm{M} \varphi$, which become vehicles for bacterial dispersion within the host (37). Studies in

352 murine brucellosis proposed that infected PMNs attenuate cellular adaptive immunity,

353 given that depletion of PMNs favored bacterial elimination $(17,38)$. Based on these,

354 this study examined the early transcriptome alterations of in vitro Brucella-infected

355 neutrophils, before their premature death. B. melitensis-infected PMNs were 
medRxiv preprint doi: https://doi.org/10.1101/2022.03.01.22271720; this version posted March 4, 2022. The copyright holder for this preprint (which was not certified by peer review) is the author/funder, who has granted medRxiv a license to display the preprint in perpetuity.

It is made available under a CC-BY-NC-ND 4.0 International license .

356 characterized by increased expression of genes associated with ribosome biogenesis

357 indicating bulk induction of protein synthesis, in an effort to arm their bactericidal

358 mechanisms and survive. Of interest and in a similar way to $\mathrm{M} \varphi$, in vitro infection of

359 PMNs with Brucella led to downregulated gene expression in key molecular pathways

360 for PMNs physiology and function including phosphatidylinositol signaling, TNF

361 signaling, and cellular senescence. Phosphatidylinositol signaling pathway plays an

362 important role in membrane dynamics and trafficking, including proteins implicated

363 in endosomal membranes and autophagosome assembly and activity $(39,40)$.

364 Autophagy is closely related to the intracellular lifestyle of many pathogens, including

365 Brucella $(41,42)$. We hypothesize that the downregulation of several autophagy

366 sensors and regulators belonging to phosphatidylinositol pathway further modulates

367 the autophagic capacity of PMNs against Brucella. This may also explain the inability

368 of Brucella-infected PMNs to form neutrophil extracellular traps (NETs) (17), an

369 effector mechanism positively associated with the autophagy machinery (43).

370 Downregulation of the cellular senescent pathway is in agreement with the reported

371 premature death of Brucella-infected PMNs (17). Additionally, senescence has been

372 associated with resistance to cellular death (44). Moreover, it appears that perturbation

373 of TNF signaling represents a common stealth strategy of Brucella to avoid both $\mathrm{M} \varphi$ -

374 and PMNs-induced inflammation further restricting cellular immunity (11).

375 In order to investigate the impact of human brucellosis in host immunity and identify

376 possible candidate markers of active disease and response to treatment, we next

377 assessed the transcriptome profiling of PBMCs and PMNs isolated from newly

378 diagnosed patients with acute brucellosis, before and three months after their

379 successful treatment. We observed, both in PBMCs and PMNs, transcriptomic

380 alterations related to major pathways of inflammation, supporting its role for infection 
381 overcome. PBMCs from patients successfully treated were characterized by the 382 overexpression of genes critically involved in hypoxia (HIFlA) and IL-1 signaling,

383 and the downregulation of genes implicated in oxidative phosphorylation, lymphocyte

384 activation, and cytotoxicity. In line with these data, a recent experimental study has

385 demonstrated that absence of HIF-1 $\alpha$ renders mice susceptible to Brucella infection,

386 while HIF-1 $\alpha$ reduces oxidative phosphorylation and increases glycolysis leading to

387 inflammasome activation and IL-1 $\beta$ release in infected macrophages (45).

388 Treatment of brucellosis upregulated in PMNs the expression of several genes related

389 to autophagy machinery, including DDIT4/REDD1 encoding a key regulator of

390 autophagy-mediated NET formation (47). It seems that after clearance of infection,

391 PMNs restored critical functions impaired by Brucella, such as autophagy. However,

392 they did not acquire a proinflammatory phenotype as indicated by the downregulated

393 expression in genes related to pathways that contain NOD-like receptor signaling and

394 cytokine-cytokine interactions.

395 Of note, this study identified a common set of 24 genes that were differentially 396 expressed both in PMNs and PBMCs suggesting candidate molecular

397 diagnostic/prognostic targets for human brucellosis. Among them, IFN pathway, 398 which is the major driver of Th1 immunity against Brucella (8), appears to be induced 399 in active disease and attenuated after treatment. Indeed, using patients' sera, we 400 confirm at the protein level, that IFN- $\gamma$ and other Th1 cytokines, such as IL-1 $\beta$ and 401 IL-6, were increased during active disease and significantly diminished in cured, non402 relapsed patients. Collectively, these results confirmed past studies highlighting the 403 significant role of a robust Th1 response to tackle acute infection and brucellosis404 acquired cellular anergy of chronic disease (47-50). 
medRxiv preprint doi: https://doi.org/10.1101/2022.03.01.22271720; this version posted March 4, 2022. The copyright holder for this preprint (which was not certified by peer review) is the author/funder, who has granted medRxiv a license to display the preprint in perpetuity.

It is made available under a CC-BY-NC-ND 4.0 International license .

405 In conclusion, this study provides an integrated transcriptome landscape of immune

406 cells signature in human brucellosis suggesting candidate molecular pathways and

407 targets for active disease and response to treatment. Based on these data, future

408 validation and mechanistic studies may further decipher the pathogenesis of this

409 ancient and continuously re-emerging zoonotic disease $(1,2,51)$. 
medRxiv preprint doi: https://doi.org/10.1101/2022.03.01.22271720; this version posted March 4, 2022. The copyright holder for this preprint (which was not certified by peer review) is the author/funder, who has granted medRxiv a license to display the preprint in perpetuity.

\section{It is made available under a CC-BY-NC-ND 4.0 International license .}

\section{Acknowledgements}

411 This study was supported by the German Federal Ministry for Education and

412 Research (BMBF) and Greek General Secretariat for Research and Technology

413 (GSRT), German-Greek Bilateral Research \& Innovation Programme BRIDGING,

414 grant MIS 5030062, and partially was supported by the GSRT, Research \& Innovation

415 Programme CYTONET, grant MIS 5048548. 
medRxiv preprint doi: https://doi.org/10.1101/2022.03.01.22271720; this version posted March 4, 2022. The copyright holder for this preprint (which was not certified by peer review) is the author/funder, who has granted medRxiv a license to display the preprint in perpetuity.

It is made available under a CC-BY-NC-ND 4.0 International license .

\section{References}

1. Dean AS, Crump L, Greter H, Schelling E, Zinsstag J. Global burden of human brucellosis: a systematic review of disease frequency. PLoS Negl Trop Dis. 2012;6(10):e1865.

2. European Food Safety Authority and European Centre for Disease Prevention and Control (EFSA and ECDC). The European Union summary report on trends and sources of zoonoses, zoonotic agents and food-borne outbreaks in 2017. EFSA J. 2018 Dec;16(12):e05500.

3. Franc KA, Krecek RC, Häsler BN, Arenas-Gamboa AM. Brucellosis remains a neglected disease in the developing world: a call for interdisciplinary action. BMC Public Health. 2018 Jan 11;18(1):125.

4. Pappas G, Akritidis N, Bosilkovski M, Tsianos E. Brucellosis. N Engl J Med. 2005 Jun 2;352(22):2325-36.

5. Pereira CR, Cotrim de Almeida JVF, Cardoso de Oliveira IR, Faria de Oliveira L, Pereira LJ, Zangerônimo MG, et al. Occupational exposure to Brucella spp.: A systematic review and meta-analysis. PLoS Negl Trop Dis. 2020 May;14(5):e0008164.

6. Pappas G, Panagopoulou P, Christou L, Akritidis N. Brucella as a biological weapon. Cell Mol Life Sci. 2006 Oct;63(19-20):2229-36.

7. Dean AS, Crump L, Greter H, Hattendorf J, Schelling E, Zinsstag J. Clinical manifestations of human brucellosis: a systematic review and meta-analysis. PLoS Negl Trop Dis. 2012;6(12):e1929.

8. Skendros P, Pappas G, Boura P. Cell-mediated immunity in human brucellosis. Microbes Infect. 2011 Feb;13(2):134-42.

9. Jiao H, Zhou Z, Li B, Xiao Y, Li M, Zeng H, et al. The Mechanism of Facultative Intracellular Parasitism of Brucella. Int J Mol Sci. 2021 Apr 1;22(7):3673.

10. Moreno E, Barquero-Calvo E. The Role of Neutrophils in Brucellosis. Microbiol Mol Biol Rev. 2020 Nov 18;84(4):e00048-20.

11. Martirosyan A, Moreno E, Gorvel J-P. An evolutionary strategy for a stealthy intracellular Brucella pathogen. Immunol Rev. 2011 Mar;240(1):211-34.

12. Skendros P, Boura P. Immunity to brucellosis. Rev Sci Tech. 2013 Apr;32(1):13747.

13. Kourtzelis I, Li X, Mitroulis I, Grosser D, Kajikawa T, Wang B, et al. DEL-1 promotes macrophage efferocytosis and clearance of inflammation. Nat Immunol. 2019 Jan;20(1):40-9.

14. Mitroulis I, Ruppova K, Wang B, Chen L-S, Grzybek M, Grinenko T, et al. Modulation of Myelopoiesis Progenitors Is an Integral Component of Trained Immunity. Cell. 2018 Jan 11;172(1-2):147-161.e12. 
medRxiv preprint doi: https://doi.org/10.1101/2022.03.01.22271720; this version posted March 4, 2022. The copyright holder for this preprint (which was not certified by peer review) is the author/funder, who has granted medRxiv a license to display the preprint in perpetuity. It is made available under a CC-BY-NC-ND 4.0 International license .

15. Afgan E, Baker D, Batut B, van den Beek M, Bouvier D, Cech M, et al. The Galaxy platform for accessible, reproducible and collaborative biomedical analyses: 2018 update. Nucleic Acids Res. 2018 Jul 2;46(W1):W537-44.

16. Lamprianidou E, Kordella C, Kazachenka A, Zoulia E, Bernard E, Filia A, et al. Modulation of IL-6/STAT3 signaling axis in CD4+FOXP3- T cells represents a potential antitumor mechanism of azacitidine. Blood Adv. 2021 Jan 12;5(1):129_ 42.

17. Barquero-Calvo E, Martirosyan A, Ordoñez-Rueda D, Arce-Gorvel V, AlfaroAlarcón A, Lepidi H, et al. Neutrophils exert a suppressive effect on Th1 responses to intracellular pathogen Brucella abortus. PLoS Pathog. 2013 Feb;9(2):e1003167.

18. de Figueiredo P, Ficht TA, Rice-Ficht A, Rossetti CA, Adams LG. Pathogenesis and immunobiology of brucellosis: review of Brucella-host interactions. Am J Pathol. 2015 Jun;185(6):1505-17.

19. Zhou Z, Gu G, Luo Y, Li W, Li B, Zhao Y, et al. Immunological pathways of macrophage response to Brucella ovis infection. Innate Immun. 2020 Oct;26(7):635-48.

20. Zhou D, Zhi F, Fang J, Zheng W, Li J, Zhang G, et al. RNA-Seq Analysis Reveals the Role of Omp16 in Brucella-Infected RAW264.7 Cells. Front Vet Sci. 2021;8:646839.

21. Solanki KS, Gandham RK, Thomas P, Chaudhuri P. Transcriptome analysis of Brucella abortus S19 $\Delta$ per immunized mouse spleen revealed activation of MHC-I and MHC-II pathways. Access Microbiol. 2020;2(1):acmi000082.

22. Hop HT, Arayan LT, Reyes AWB, Huy TXN, Min W, Lee HJ, et al. Simultaneous RNA-seq based transcriptional profiling of intracellular Brucella abortus and B. abortus-infected murine macrophages. Microb Pathog. 2017 Dec;113:57-67.

23. Liu Q, Han W, Sun C, Zhou L, Ma L, Lei L, et al. Deep sequencing-based expression transcriptional profiling changes during Brucella infection. Microb Pathog. 2012 Dec;52(5):267-77.

24. Rossetti CA, Galindo CL, Everts RE, Lewin HA, Garner HR, Adams LG. Comparative analysis of the early transcriptome of Brucella abortus--infected monocyte-derived macrophages from cattle naturally resistant or susceptible to brucellosis. Res Vet Sci. 2011 Aug;91(1):40-51.

25. Wang F, Hu S, Liu W, Qiao Z, Gao Y, Bu Z. Deep-sequencing analysis of the mouse transcriptome response to infection with Brucella melitensis strains of differing virulence. PLoS One. 2011;6(12):e28485.

26. Jubier-Maurin V, Boigegrain RA, Cloeckaert A, Gross A, Alvarez-Martinez MT, Terraza A, et al. Major outer membrane protein Omp25 of Brucella suis is involved in inhibition of tumor necrosis factor alpha production during infection of human macrophages. Infect Immun. 2001 Aug;69(8):4823-30. 
medRxiv preprint doi: https://doi.org/10.1101/2022.03.01.22271720; this version posted March 4, 2022. The copyright holder for this preprint (which was not certified by peer review) is the author/funder, who has granted medRxiv a license to display the preprint in perpetuity. It is made available under a CC-BY-NC-ND 4.0 International license .

27. Caron E, Gross A, Liautard JP, Dornand J. Brucella species release a specific, protease-sensitive, inhibitor of TNF-alpha expression, active on human macrophage-like cells. J Immunol. 1996 Apr 15;156(8):2885-93.

28. Billard E, Dornand J, Gross A. Brucella suis prevents human dendritic cell maturation and antigen presentation through regulation of tumor necrosis factor alpha secretion. Infect Immun. 2007 Oct;75(10):4980-9.

29. Costa Franco MMS, Marim FM, Alves-Silva J, Cerqueira D, Rungue M, Tavares IP, et al. AIM2 senses Brucella abortus DNA in dendritic cells to induce IL-1 $\beta$ secretion, pyroptosis and resistance to bacterial infection in mice. Microbes Infect. 2019 Mar;21(2):85-93.

30. Lacey CA, Mitchell WJ, Dadelahi AS, Skyberg JA. Caspase-1 and Caspase-11 Mediate Pyroptosis, Inflammation, and Control of Brucella Joint Infection. Infect Immun. 2018 Sep;86(9):e00361-18.

31. Gomes MTR, Campos PC, Oliveira FS, Corsetti PP, Bortoluci KR, Cunha LD, et al. Critical role of ASC inflammasomes and bacterial type IV secretion system in caspase-1 activation and host innate resistance to Brucella abortus infection. $\mathbf{J}$ Immunol. 2013 Apr 1;190(7):3629-38.

32. Jakka P, Namani S, Murugan S, Rai N, Radhakrishnan G. The Brucella effector protein TcpB induces degradation of inflammatory caspases and thereby subverts non-canonical inflammasome activation in macrophages. J Biol Chem. 2017 Dec 15;292(50):20613-27.

33. Campos PC, Gomes MTR, Marinho FAV, Guimarães ES, de Moura Lodi Cruz MGF, Oliveira SC. Brucella abortus nitric oxide metabolite regulates inflammasome activation and IL- $1 \beta$ secretion in murine macrophages. Eur $\mathbf{J}$ Immunol. 2019 Jul;49(7):1023-37.

34. Skendros P, Papagoras C, Mitroulis I, Ritis K. Autoinflammation: Lessons from the study of familial Mediterranean fever. J Autoimmun. 2019 Nov;104:102305.

35. Özen S. Update on the epidemiology and disease outcome of Familial Mediterranean fever. Best Pract Res Clin Rheumatol. 2018 Apr;32(2):254-60.

36. Ross JJ. Goats, germs, and fever: Are the pyrin mutations responsible for familial Mediterranean fever protective against Brucellosis? Med Hypotheses. 2007;68(3):499-501.

37. Gutiérrez-Jiménez C, Mora-Cartín R, Altamirano-Silva P, Chacón-Díaz C, Chaves-Olarte E, Moreno E, et al. Neutrophils as Trojan Horse Vehicles for Brucella abortus Macrophage Infection. Front Immunol. 2019;10:1012.

38. Mora-Cartín R, Gutiérrez-Jiménez C, Alfaro-Alarcón A, Chaves-Olarte E, Chacón-Díaz C, Barquero-Calvo E, et al. Neutrophils Dampen Adaptive Immunity in Brucellosis. Infect Immun. 2019 Mar;87(5):e00118-19. 
medRxiv preprint doi: https://doi.org/10.1101/2022.03.01.22271720; this version posted March 4, 2022. The copyright holder for this preprint (which was not certified by peer review) is the author/funder, who has granted medRxiv a license to display the preprint in perpetuity. It is made available under a CC-BY-NC-ND 4.0 International license .

39. Baba T, Balla T. Emerging roles of phosphatidylinositol 4-phosphate and phosphatidylinositol 4,5-bisphosphate as regulators of multiple steps in autophagy. J Biochem. 2020 Oct 1;168(4):329-36.

40. Claude-Taupin A, Morel E. Phosphoinositides: Functions in autophagy-related stress responses. Biochim Biophys Acta Mol Cell Biol Lipids. 2021 Jun;1866(6):158903.

41. Starr T, Child R, Wehrly TD, Hansen B, Hwang S, López-Otin C, et al. Selective subversion of autophagy complexes facilitates completion of the Brucella intracellular cycle. Cell Host Microbe. 2012 Jan 19;11(1):33-45.

42. Skendros P, Mitroulis I. Host cell autophagy in immune response to zoonotic infections. Clin Dev Immunol. 2012;2012:910525.

43. Skendros P, Mitroulis I, Ritis K. Autophagy in Neutrophils: From Granulopoiesis to Neutrophil Extracellular Traps. Front Cell Dev Biol. 2018;6:109.

44. Sasaki M, Kumazaki T, Takano H, Nishiyama M, Mitsui Y. Senescent cells are resistant to death despite low Bcl-2 level. Mech Ageing Dev. 2001 Oct;122(15):1695-706.

45. Gomes MTR, Guimarães ES, Marinho FV, Macedo I, Aguiar ERGR, Barber GN, et al. STING regulates metabolic reprogramming in macrophages via HIF-1 $\alpha$ during Brucella infection. PLoS Pathog. 2021 May;17(5):e1009597.

46. Skendros P, Chrysanthopoulou A, Rousset F, Kambas K, Arampatzioglou A, Mitsios A, et al. Regulated in development and DNA damage responses 1 (REDD1) links stress with IL-1 $\beta$-mediated familial Mediterranean fever attack through autophagy-driven neutrophil extracellular traps. J Allergy Clin Immunol. 2017 Nov;140(5):1378-1387.e13.

47. Giambartolomei GH, Delpino MV, Cahanovich ME, Wallach JC, Baldi PC, Velikovsky CA, et al. Diminished production of T helper 1 cytokines correlates with $\mathrm{T}$ cell unresponsiveness to Brucella cytoplasmic proteins in chronic human brucellosis. J Infect Dis. 2002 Jul 15;186(2):252-9.

48. Rafiei A, Ardestani SK, Kariminia A, Keyhani A, Mohraz M, Amirkhani A. Dominant Th1 cytokine production in early onset of human brucellosis followed by switching towards Th2 along prolongation of disease. J Infect. 2006 Nov;53(5):315-24.

49. Skendros P, Boura P, Chrisagis D, Raptopoulou-Gigi M. Diminished percentage of CD4+ T-lymphocytes expressing interleukine-2 receptor alpha in chronic brucellosis. J Infect. 2007 Feb;54(2):192-7.

50. Skendros P, Sarantopoulos A, Tselios K, Boura P. Chronic brucellosis patients retain low frequency of CD4+ T-lymphocytes expressing CD25 and CD28 after Escherichia coli LPS stimulation of PHA-cultured PBMCs. Clin Dev Immunol. 2008;2008:327346. 
medRxiv preprint doi: https://doi.org/10.1101/2022.03.01.22271720; this version posted March 4, 2022. The copyright holder for this preprint (which was not certified by peer review) is the author/funder, who has granted medRxiv a license to display the preprint in perpetuity.

It is made available under a CC-BY-NC-ND 4.0 International license.

51. Godfroid J, Cloeckaert A, Liautard J-P, Kohler S, Fretin D, Walravens K, et al. From the discovery of the Malta fever's agent to the discovery of a marine mammal reservoir, brucellosis has continuously been a re-emerging zoonosis. Vet Res. 2005 Jun;36(3):313-26. 
medRxiv preprint doi: https://doi.org/10.1101/2022.03.01.22271720; this version posted March 4, 2022. The copyright holder for this preprint (which was not certified by peer review) is the author/funder, who has granted medRxiv a license to display the preprint in perpetuity.

It is made available under a CC-BY-NC-ND 4.0 International license .

417 Table 1. Characteristics of patients with acute brucellosis (AB).

\begin{tabular}{|c|c|c|c|c|c|c|c|}
\hline Patient\# & Sex & $\begin{array}{c}\text { Age } \\
\text { (decade) }\end{array}$ & $\begin{array}{l}\text { Symptoms/ } \\
\text { Findings }\end{array}$ & $\begin{array}{c}\text { Route of } \\
\text { transmission }\end{array}$ & $\begin{array}{l}\text { Wright } \\
\text { SAT }\end{array}$ & $\begin{array}{c}\text { Blood } \\
\text { culture }\end{array}$ & $\begin{array}{l}\text { Antibiotic } \\
\text { treatment }\end{array}$ \\
\hline $\mathrm{AB} 1$ & $\mathrm{~F}$ & 4 th & $\begin{array}{c}\text { Fatigue, malaise } \\
\text { myalgias, arthralgias }\end{array}$ & Consumption & $1 / 640$ & N/A & $\begin{array}{c}\text { Rifampicin } \\
\text { Doxycycline }\end{array}$ \\
\hline AB2 & $\mathrm{F}$ & 6 th & $\begin{array}{l}\text { Fever, sweating, } \\
\text { arthralgias, peripher- } \\
\text { al arthritis }\end{array}$ & Consumption & $1 / 320$ & Negative & $\begin{array}{l}\text { Rifampicin } \\
\text { Doxycycline } \\
\text { Amikacin }\end{array}$ \\
\hline AB3 & M & 4 th & $\begin{array}{l}\text { Fever, sweating, fa- } \\
\text { tigue }\end{array}$ & $\begin{array}{l}\text { Consumption, } \\
\text { contact }\end{array}$ & $1 / 320$ & Negative & $\begin{array}{l}\text { Rifampicin } \\
\text { Doxycycline } \\
\text { Amikacin }\end{array}$ \\
\hline $\mathrm{AB} 4$ & M & 4 th & $\begin{array}{l}\text { Fever, sweating, ma- } \\
\text { laise, fatigue }\end{array}$ & Consumption & $1 / 5120$ & Negative & $\begin{array}{l}\text { Rifampicin } \\
\text { Doxycycline } \\
\text { Amikacin }\end{array}$ \\
\hline AB5 & M & 6 th & $\begin{array}{l}\text { Fever, sweating, } \\
\text { lumbar spondylitis }\end{array}$ & Contact & $1 / 160$ & Brucella & $\begin{array}{l}\text { Rifampicin } \\
\text { Doxycycline } \\
\text { Amikacin }\end{array}$ \\
\hline AB6 & M & 7 th & Fever, myalgia & Contact & $1 / 320$ & Brucella & $\begin{array}{l}\text { Rifampicin } \\
\text { Doxycycline } \\
\text { Amikacin }\end{array}$ \\
\hline AB7 & M & 7 th & $\begin{array}{l}\text { Sweating, fatigue, } \\
\text { low back pain }\end{array}$ & Consumption & $1 / 320$ & Brucella & $\begin{array}{l}\text { Rifampicin } \\
\text { Doxycycline } \\
\text { Amikacin }\end{array}$ \\
\hline AB8 & $\mathrm{F}$ & 5 th & $\begin{array}{l}\text { Fatigue, lumbar } \\
\text { spondylitis }\end{array}$ & Consumption & $1 / 640$ & N/A & $\begin{array}{l}\text { Rifampicin } \\
\text { Doxycycline } \\
\text { Amikacin }\end{array}$ \\
\hline AB9 & M & 6 th & $\begin{array}{l}\text { Fever, sweating, ma- } \\
\text { laise, fatigue } \\
\text { myalgias, arthralgias }\end{array}$ & $\begin{array}{l}\text { Consumption, } \\
\text { contact }\end{array}$ & $1 / 160$ & Brucella & $\begin{array}{l}\text { Rifampicin } \\
\text { Doxycycline } \\
\text { Amikacin }\end{array}$ \\
\hline $\mathrm{AB} 10$ & M & 6th & $\begin{array}{l}\text { Fatigue, myalgias, } \\
\text { arthralgias, peripher- } \\
\text { al arthritis }\end{array}$ & $\begin{array}{l}\text { Contact/REV1 } \\
\text { vaccine }\end{array}$ & $1 / 160$ & Negative & $\begin{array}{l}\text { Rifampicin } \\
\text { Doxycycline }\end{array}$ \\
\hline \multicolumn{2}{|c|}{$\begin{array}{c}\text { Age (years, } \\
\text { mean } \pm S D)\end{array}$} & $50.0 \pm 11.6$ & & & & & \\
\hline
\end{tabular}

418

419 F; female, M; male, N/A; not available, SAT; serum agglutination test, SD; standard deviation

420 Duration of antibiotic treatment was 8-12 weeks for rifampicin (600 mg/daily) and

421 doxycycline (200 mg/daily), and 2-3 weeks for Amikacin (1 gr/daily). 
medRxiv preprint doi: https://doi.org/10.1101/2022.03.01.22271720; this version posted March 4, 2022. The copyright holder for this preprint (which was not certified by peer review) is the author/funder, who has granted medRxiv a license to display the preprint in perpetuity.

It is made available under a CC-BY-NC-ND 4.0 International license .

\section{Figure legends}

423 Figure 1. Alterations in the transcriptomic profile of human $\mathrm{M} \varphi$ infected in vitro

424 with B. melitensis. (A) Principal component analysis (PCA) of the transcriptome of 425 all $12 \mathrm{M} \varphi$ samples. T1-T4 represent untreated control M $\varphi$, T11-T14 represent samples 426 from $\mathrm{M} \varphi$ at $2 \mathrm{~h}$ post infection and T21-T24 represent samples at the $24 \mathrm{~h}$ time point.

427 (B) Pathway analysis of the DEGs at $2 \mathrm{~h}$ post-infection compared to control, using the 428 KEGG database as reference. Light blue color represents statistical significance (C) 429 Heatmaps depicting the DEGs of the respective pathways. (D) Pathway analysis of 430 the DEGs with the highest variance at $24 \mathrm{~h}$ post infection compared to control, using 431 the KEGG database as reference. (E) Enriched biological processes in which the 432 downregulated genes are involved. (F) Heatmaps depicting the DEGs of the 433 phagosome pathway, the inflammatory response and positive regulation of IL-1 $\beta$ 434 production biological processes.

435 Figure 2. Alterations in the transcriptomic profile of human PMNs infected in 436 vitro with B. melitensis. (A) Pathway analysis of the DEGs from PMNs at $0.5 \mathrm{~h}$ post 437 infection with $B$. melitensis compared to control, using the KEGG database as 438 reference. (B) Heatmap depicting the DEGs of the ribosome pathway. (C) Heatmap 439 depicting the DEGs of the pathways enriched for downregulated genes.

440 Figure 3. Transcriptomic analysis of PMNs from patients with brucellosis before 441 treatment initiation and after successful completion of treatment. (A) Pathway 442 analysis of the DEGs from PMNs after treatment compared to PMNs isolated from 443 the same patients (paired-data analysis) during active brucellosis, using the KEGG 444 database as reference. Light blue color represents statistical significance (B) 445 Heatmaps depicting the DEGs of the respective pathways. P1-P8 refers to different 446 patients. (C) GSEA for genes related to response to interferons, and inflammation. 
medRxiv preprint doi: https://doi.org/10.1101/2022.03.01.22271720; this version posted March 4, 2022. The copyright holder for this preprint (which was not certified by peer review) is the author/funder, who has granted medRxiv a license to display the preprint in perpetuity.

It is made available under a CC-BY-NC-ND 4.0 International license.

447 Figure 4. Transcriptomic analysis of PBMCs from patients with brucellosis

448 before treatment initiation and after successful completion of treatment. (A)

449 Heatmap depicting the DEGs from PBMCs from patients with acute brucellosis

450 before treatment initiation and from the same patients (paired analysis) after

451 successful treatment. P1-P6 refers to different patients. (B) GSEA for genes related to

452 response to interferons, oxidative phosphorylation and hypoxia. (C) Venn diagram and

453 (D) heatmap depicting the common genes that were significantly differentially

454 expressed in PMNs and PBMCs from patients with brucellosis after treatment.

455 Figure 5. Levels of cytokines in the serum of patients with active brucellosis. (A-

456 H) Levels of IFN- $\alpha$, IFN- $\gamma$, IL-1 $\beta$, IL-18, TNF, IL-6, MCP-1 and IL-17A in the serum

457 of patients with acute brucellosis before treatment initiation and after successful

458 treatment. (I) Levels of IFN- $\gamma$ in patients with chronic relapsing brucellosis during

459 relapse and remission. ${ }^{*} \mathrm{p}<0.05, * * \mathrm{p}<0.01$. Wilcoxon signed rank test. 

Figure 2

A

KEGG_PMN_0.5h vs Ctrl_up

Ribosome

Coronavirus disease

Parkinson disease

Prion disease

Oxidative phosphorylation

Huntington disease

Non-alcoholic fatty liver disease

Amyotrophic lateral sclerosis

Diabetic cardiomyopathy

Pathways of neurodegeneration

10
B

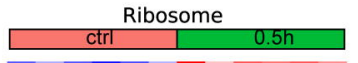

MRPS1

RPS9

MRPS18A

RPL36AL

FAU

UBA52

MRPS2

RPLP2

RPS8

RPL8

RPL9

RPS21

RPL34

RPL39

RPS13

RPS27A

RPL5

RPL31

RPL7

RPS3A

RPS12

RPL24

RPL10A

RPS23

RPS4X

RPL4

RPL14

RPSA

RPS5

RPL3

RPL10

$R P L 15$

RPS24

RPLP1

RPLPO

RPL36

RPL18A

$\mathrm{RP} \perp 32$

RPL35

RPS19

RPL19

RPL13A

RPS6

RPS2

RPL12

RPL13

RPS27

RPL22

RPS7

RPL6

RPL26

RPL23

RPS15A

RPS25

RPS20

RPL38

RPL37

RPL30

RPL28

RPS15

RPS16

RPL 18

RPS14

RPL37A

RPL27

RPS28

RPL7A

RPL29

RPL11

RPS3

RPL23A

RPL35A

RPL27A

RPS11

RPS29

MRPL23

RPL41

MRPS5

MRPS21

MRPL11

MRPL24

RPL22L1

RPS 26

RPS4Y1

MRPL28 
A

RNA transport

Autophagy

C-type lectin receptor signaling pathway

Parathyroid hormone synthesis, secretion and action

Epithelial cell signaling in Helicobacter pylori infection

Synaptic vesicle cycle

mRNA surveillance pathway

Hematopoietic cell lineage

NF-kappa B signaling pathway

Ribosome biogenesis in eukaryotes

${ }^{1}-\log _{10}(p-v a l u e)$

B

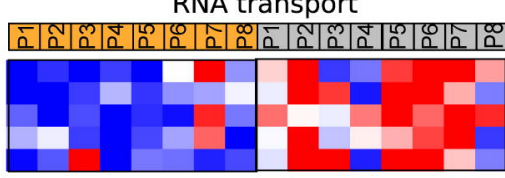

Autophagy

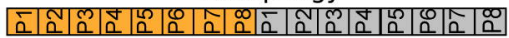
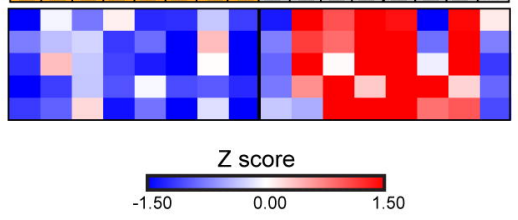

HALLMARK_INTERFERON_GAMMA_RESPONSE

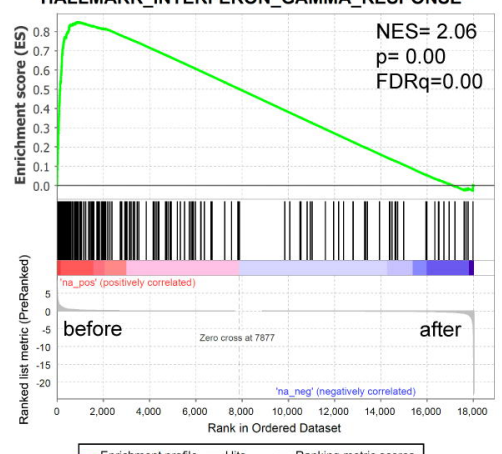

-Enrichment profile - Hits - Ranking metric scores
ATG2A GABARAPL TP53INP2 DDIT4 IRS2

EIF1

EIF3I

EIF4A3

EIF5

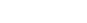

KEGG_down after treatment

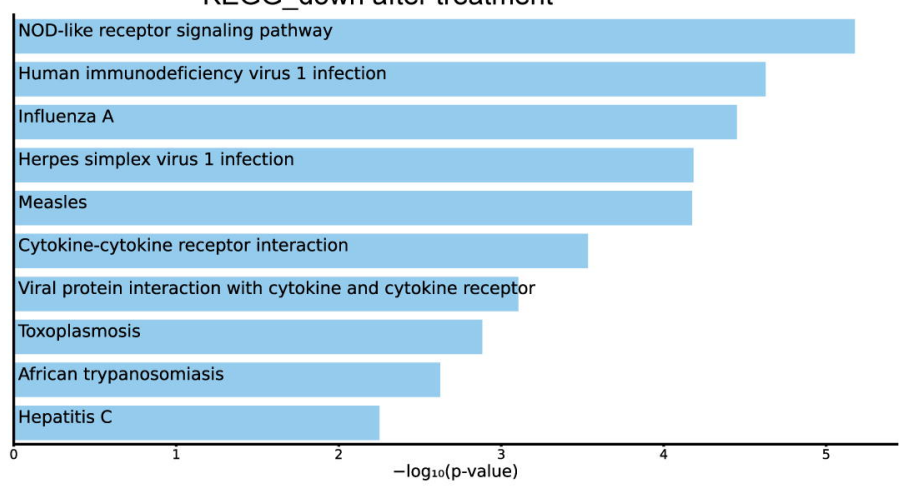

NOD-like receptor signaling pathway

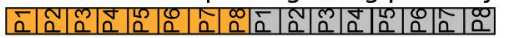

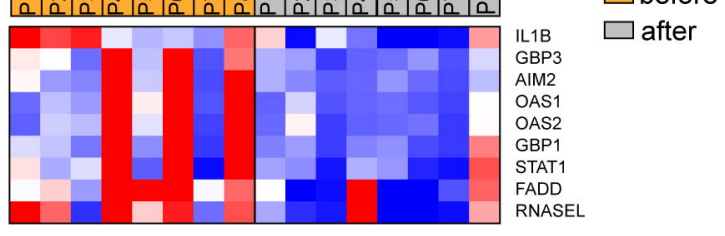

Cytokine-cytokine receptor interaction

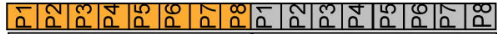

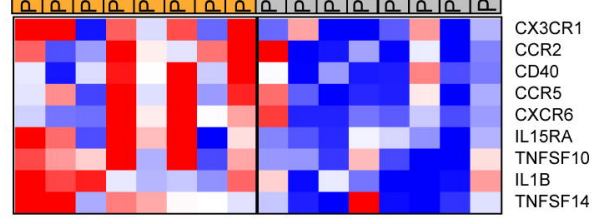

HALLMARK INTERFERON_ALPHA_RESPONSE

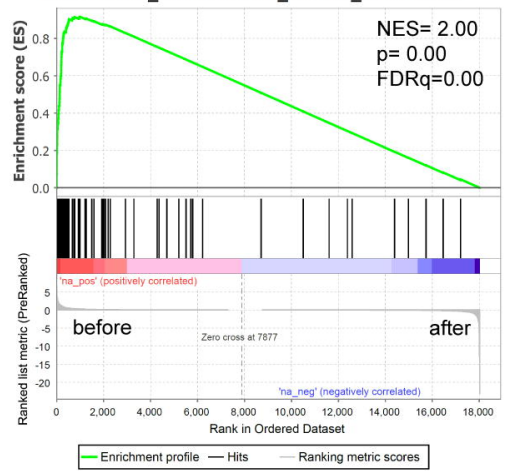

HALLMARK_INFLAMMATORY_RESPONSE

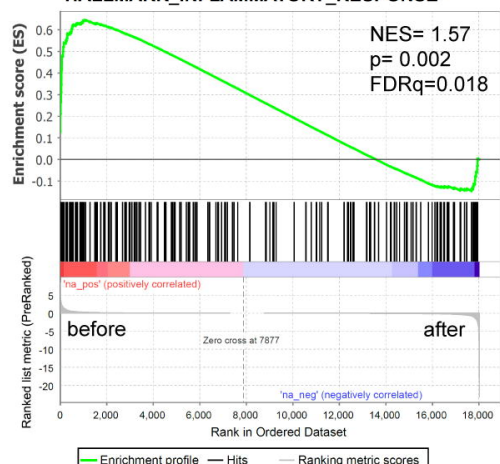


A
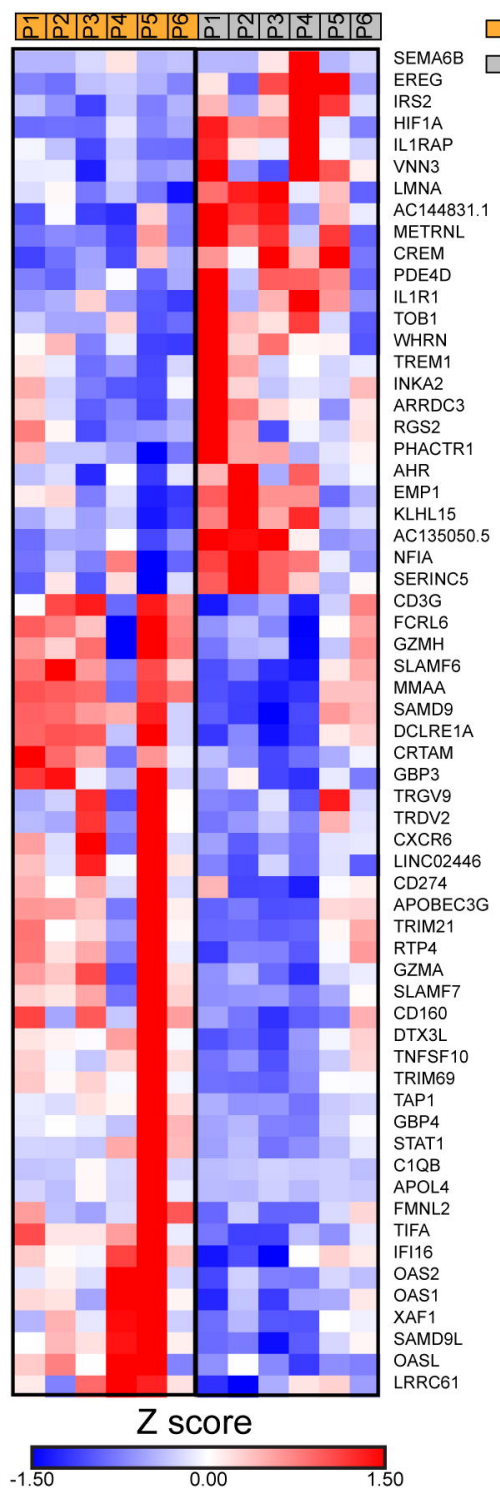

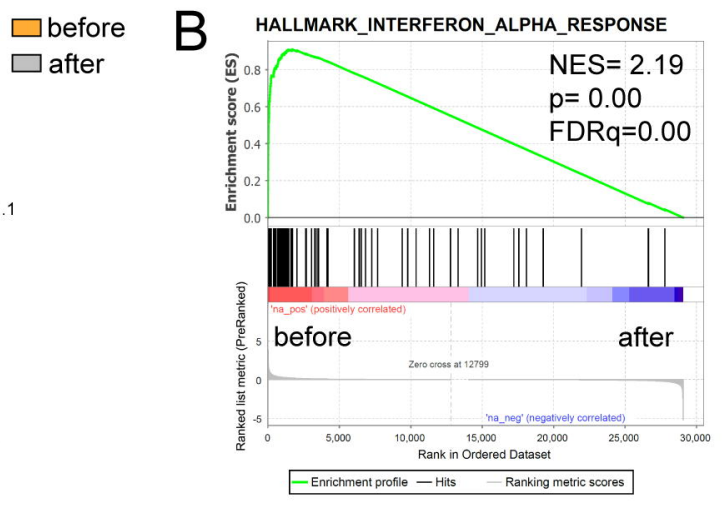

HALLMARK_OXIDATIVE_PHOSPHORYLATION

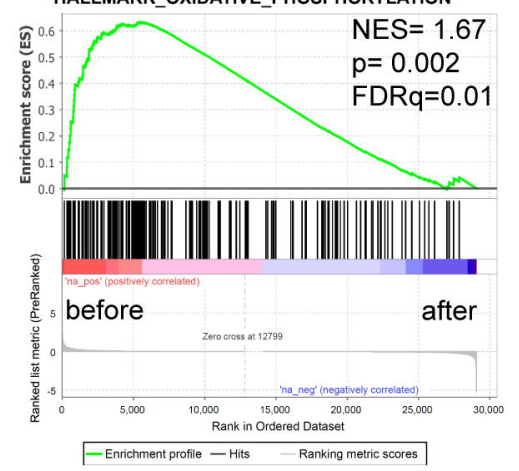

C

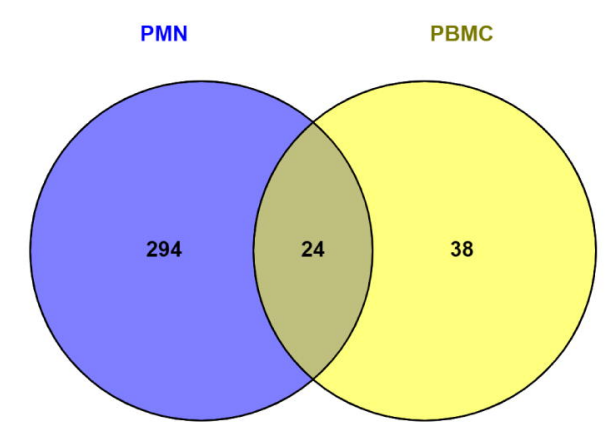

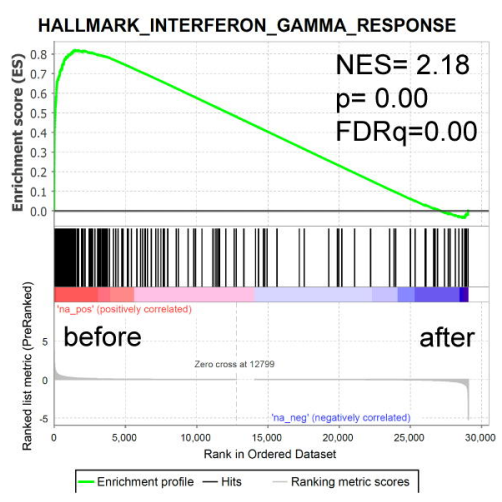

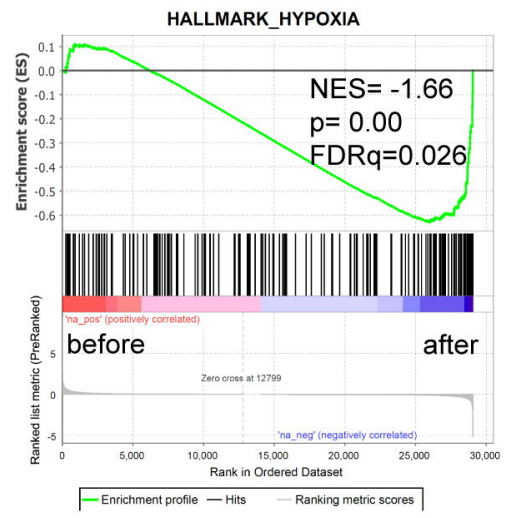

D

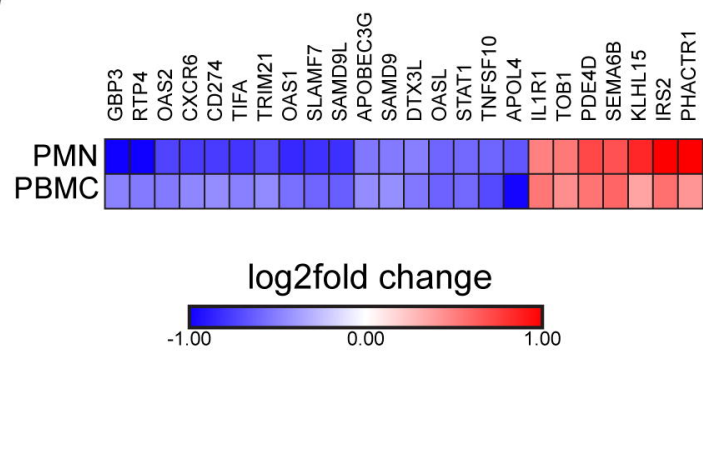


A

IFNa B

IFNY

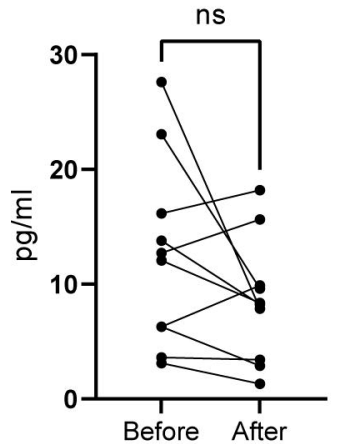

E

TNF

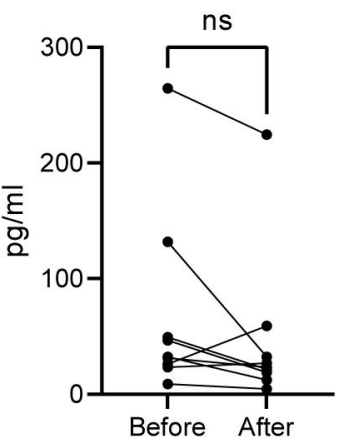

IFNy

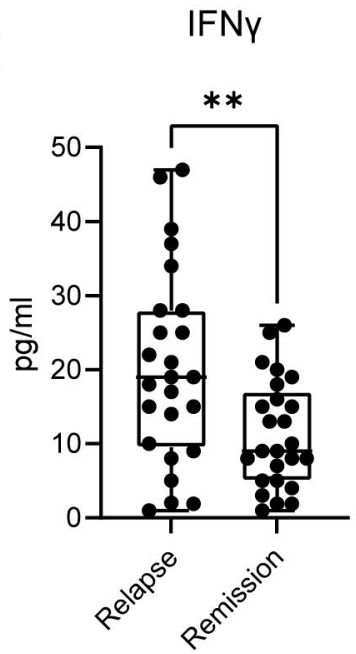

I

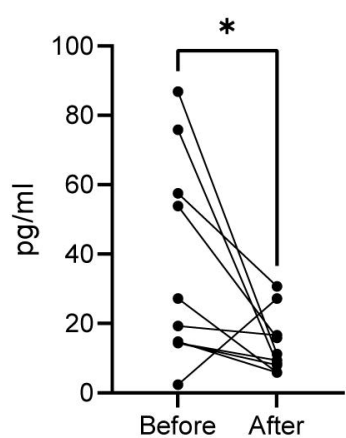

F

IL-6

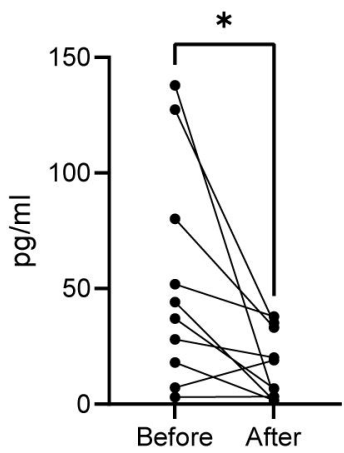

C

IL-1

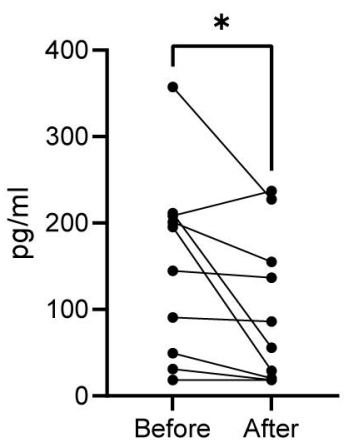

G

$$
\text { MCP-1 }
$$

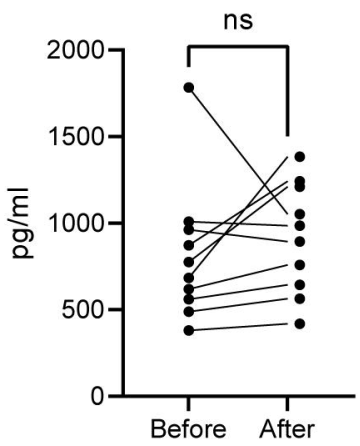

D IL-18

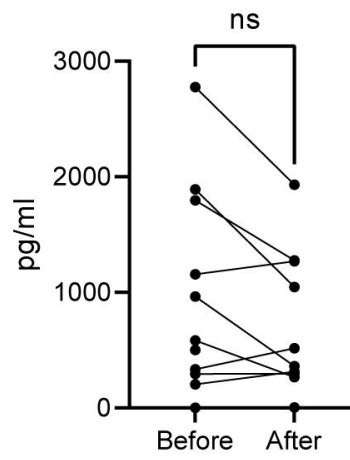

$\mathrm{H}$

$$
\text { IL-17A }
$$

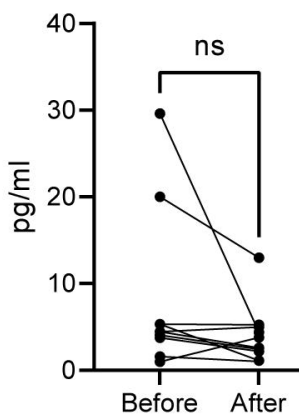

